Santana-Quintero, M. Addison, A. C.

\title{
Digital tools for heritage information management and protection: the need of training
}

\author{
Mario Santana-Quintero ${ }^{1}$ Alonzo C. Addison ${ }^{2}$
}

${ }^{1}$ R. Lemaire International Centre for Conservation, Katholieke Univeristeit Leuven, kasteelpark Arenberg 1, B3001 Heverlee, Belgium; ${ }^{2}$ UNESCO World Heritage Centre, 7, Place de Fontenoy, F-75352 Paris, France

\{mario.santana@asro.kuleuven.be, a.ddison@unesco.org\}

\begin{abstract}
This paper is aimed at demonstrating the need of training material for the design and deployment of cultural heritage resource information systems in management and protection. Heritage information plays an essential role in the adequate preparation, implementation and monitoring of conservation strategies. Good decisions in conservation are based on the information available and, in this sense, the use of information systems are needed for providing timely and relevant collection, storage, management and presentation of cultural heritage.
\end{abstract}

Keywords: architecture, cultural heritage, information systems, conservation, multimedia, recording, and documentation.

\section{Introduction}

This manuscript seeks to explore the need of guidelines for the design and deploy of digital tools directed at the global understanding of the significance of heritage sites and the threats affecting its integrity and for decision-making.

A digital system should be based on recording and managing indicators that are capable of providing information about the degree of impact to the site, providing potential stakeholders with a tool to be able to make decision about interventions aimed at protecting heritage effectively.

In addition, the development strategy should involve the consultation with stakeholders and users of the system, including operators and information providers. This will ensure an adequate deployment of a system that is both adapted to local needs to take care of cultural heritage. 


\subsection{Building a heritage information system: dogmas}

The preparation of heritage information systems often is confronted with dogmas preventing the definition of an adequate approach. Generally, these dogmas can be classified according to the following list:

1. The World Heritage dogma: all sites are considered worth of universal importance, lack of revision of the current international and national legal framework governing the operation of a system prevents the system designer to propose an approach that will improve institutional operations to protect heritage;

2. The 3D-4D dogma in completeness of information: usually system designers are confronted with an inadequate definition of level of recording: everything needs to be documented to the full extend, this prevents to understand the minimal requirements of a system to timely and effectively collect and manage information

3. The digital anastylosis: everything needs to be reconstructed virtually, this dogma is associated to dogma 2 , this prevents effective heritage information assessment, we don't need to know exactly how a column is built to be able to protect it;

4. High tech provides more information of low tech: this dogma prevents the system designer to identify a effective and suitable approach, a misunderstanding about long and short term investment; as well, as capacity of the institution;

5. Scale vs the accuracy: this dogma prevents the designer to understand the need of a defined level of detail and the adequate assessment of existing information before deploying a system;

6. Re-inventing the wheel: this prevents not assessing and adopting standards and guidelines;

7. The heritage information specialist: this dogma prevents the designer to understand the need of multidisciplinary approach to designing and deploying a system.

\subsection{Operability issues}

'After conservation intervention, documentation provides the basis for monitoring, management, and routine maintenance of a site, as well as a record for posterity' (Eppich, R. LeBlanc, F. 2006).

This statement clearly identifies the need of recording for posterity, in terms of heritage information system, this issue has not been developed consistently, the issue of preserving electronic data is a critical issue.

Longevity: deals with life expectancy in an average number of years of media, where heritage information systems is stored and disseminated, figure 1 shows the life expectancy of media in terms of years and this arises the issues of how ensuring data 
now stored in electronic media is preserve for the future, very little has been done in this field in relation with built heritage, however several initiatives in the field of library are currently developed, perhaps it is worthwhile to involve these groups in the discussion about media generated from inventories of built heritage (movable and immovable).

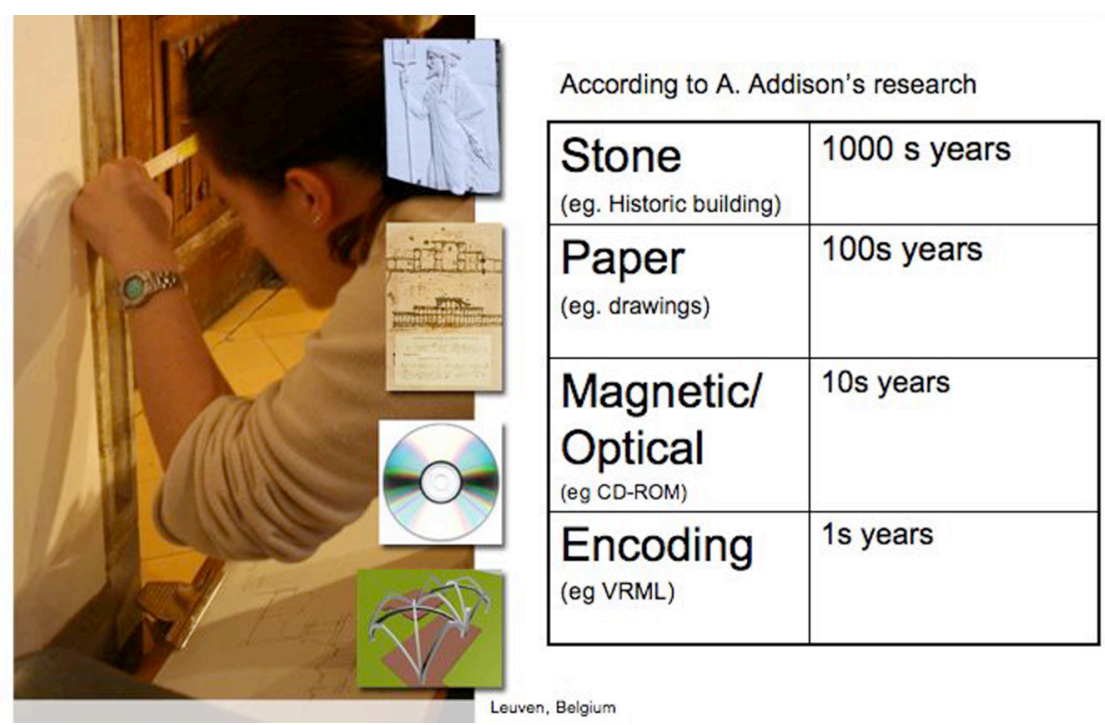

Figure 1: storage media longevity issues, according to Addison's approach.

Compatibility: upgrading systems and addressing new needs is an expanding problem in the application of information systems, in this case the use of metadata to define data collected is crucial, since electronic equipment and software might constantly evolve in the future, upgrading should be an integral part of any strategy to deploy an information system.

\section{Heritage Information system's objectives for conservation}

Cultural heritage is a unique and irreplaceable source of information. The heritage information acquired serves for the identification and classification of objects, for the development of adequate policies for its conservation and maintenance, as well as to promote identity and cultural tourism.

The objectives of a system should allow:

- Knowledge that permits the advance of understanding of the cultural heritage, its significant and integrity; 
- Promote the interest and involvement of the people in the preservation of the heritage through the dissemination of acquired information;

- Permit informed decision for management and control of interventions changing the fabric of cultural heritage;

- Ensure that the maintenance and conservation of the heritage, related to its integrity (physical form, materials, construction, etc) and its historical and cultural significance.

Additionally, a system should also permit monitoring the following issues threatening the management of sites (Palumbo, G.):

- Demographic growth around and inside the site;

- Urban encroachment condition;

- Potential infrastructures development;

- Modifications of land-use;

- Lack of integrated planning;

- $\quad$ Lack of heritage surveys

- $\quad$ Lack of knowledge of condition and status of cultural heritage.

\section{Heritage information indicators}

Indicators allow identifying threats to heritage by recording variables or measures that potentially can supply information about what is happening in a heritage site, when it is not possible to monitor or measure every component of the environment due to technical and/or financial constraints.

\subsection{Identifying heritage indicators}

A convenient approach is to identify the heritage site issues by using the strengths, weaknesses, opportunities and threats (SWOT) approach. It should take into consideration issues affecting:

- Physical condition (weathering forms);

- $\quad$ Significance - Integrity - values;

- Interpretation - Perception;

- Other issues to be identified, according to the nature of the heritage site.

Usual factors to consider affecting heritage sites (Parks Canada) that should be considered when defining indicators:

- Development Pressures

- Environmental Pressures

- Natural Disasters and Preparedness

- Visitor/tourism Pressures

- Number of inhabitants within property, buffer zone

- Threat of armed-conflict 


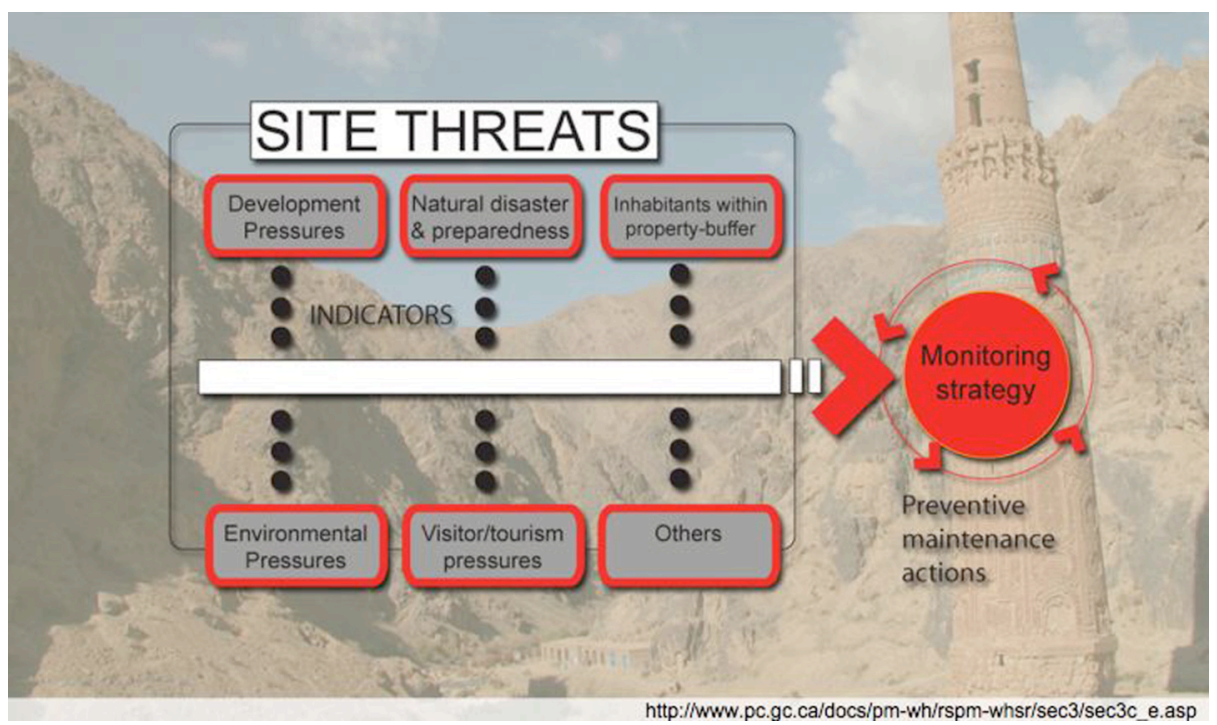

Figure 2: site threats in defining indicators, author based on Park Canada's approach.

The evaluation of these threats and the corresponding indicators will allow to ensure a monitoring system, where a heritage information system will play a crucial role to record information about these indicators.

\section{Types of heritage information systems}

The following Table, as being prepared as a guideline to the current practices in preparing Heritage information systems:

Table 1. Types of heritage information systems.

\begin{tabular}{|c|c|c|c|}
\hline Types & Pro's & Con's & Example \\
\hline $\begin{array}{l}\text { Paper inventories } \\
\text { and catalogues }\end{array}$ & Easy to visualize and share & $\begin{array}{l}\text { Difficult to } \\
\text { retrieve } \\
\text { information if not } \\
\text { well indexed }\end{array}$ & $\begin{array}{l}\text { http://www.nps.gov/hist } \\
\text { ory/hdp/standards/CRGI } \\
\text { S/paper.htm }\end{array}$ \\
\hline $\begin{array}{l}\text { Electronic } \\
\text { databases }\end{array}$ & $\begin{array}{l}\text { Interaction with other } \\
\text { inventories is difficult }\end{array}$ & Indexing is easy & $\begin{array}{l}\text { http://www.kikirpa.be/w } \\
\text { ww2/en/doc/docu.htm }\end{array}$ \\
\hline $\begin{array}{l}\text { Geographic } \\
\text { Information } \\
\text { Systems (GIS) }\end{array}$ & Data integration easy & $\begin{array}{l}\text { Requires } \\
\text { considerable input } \\
\text { of mapping } \\
\text { information }\end{array}$ & http://www.timemap.net \\
\hline $\begin{array}{l}\text { Online GIS with } \\
\text { spatial imagery }\end{array}$ & $\begin{array}{l}\text { Combines advantages of GIS } \\
\text { with an intuitive and easy to }\end{array}$ & & http://earth.google.com/ \\
\hline
\end{tabular}


understand «real»

\section{Defining a baseline}

Indicators, explained previously provide a guide to the issue to be recorded for the monitoring of the site, additionally to the indicators a the subsequent baseline definition involves a 'mapping effort'.

This mapping effort consists in prior to survey anything, to review and identify gaps in the existing information (documentation) on the site. This first assessment will allow estimate the degree of additional recording work required to prepare an adequate set of documents to mapped indicators.

The following checklist can be used as guideline to minimum requirements of information required to define the baseline:

- Identify site location (centroid, boundaries, elements and buffer zone);

- Identify and map evidences of criteria;

- $\quad$ Significance and integrity assessment;

- Risk assessment: threats and hazards associated to indicators;

- Administrative and management issues (current and passed mitigations);

- Other assessments.

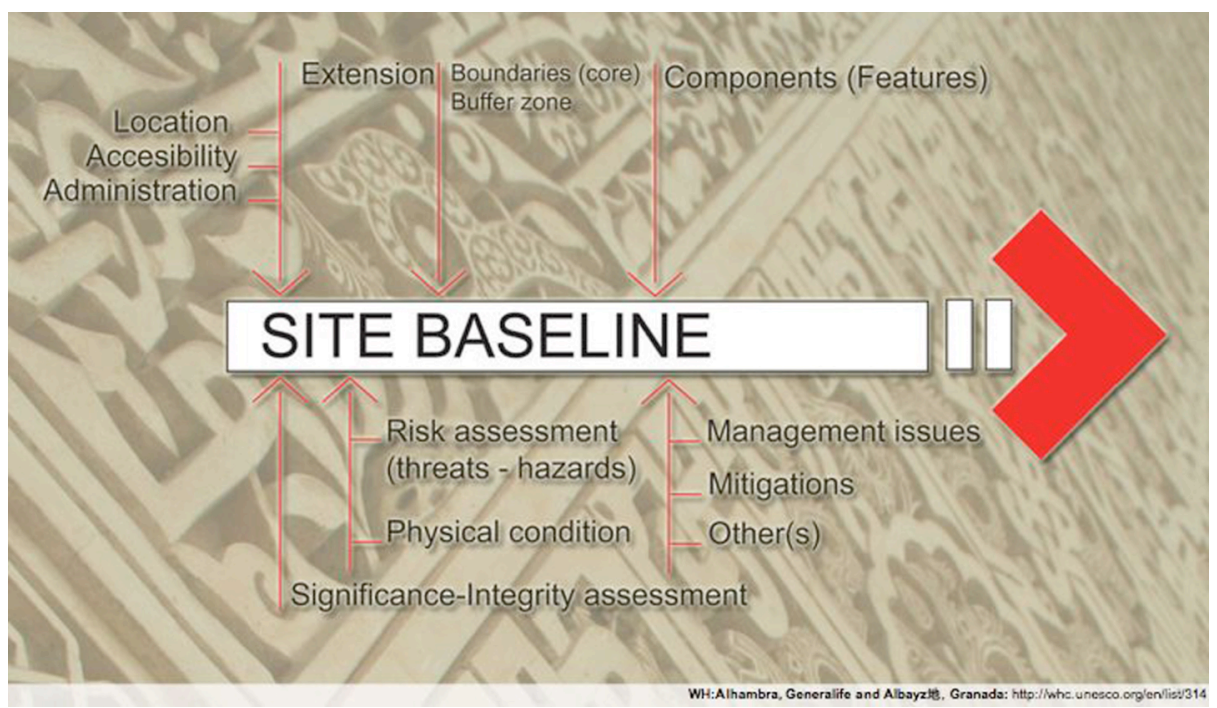


Figure 3: defining the site baseline, author.

\section{Digital sensors}

Digital sensors to register, document and record cultural heritage, these can be classified according Addison's approach in the following categories:

- Visual (Still and video cameras)

- Dimensional (surveying, 3D scanning, photogrammetry, metrology, GPR)

- $\quad$ Locational (GPS, compass, ...)

- Environmental (thermal, acoustic, $\mathrm{C} 14, \ldots$ )

Visual: technology capable of providing a visible impression of colour, shape and motion of a scene.

Dimensional: technology capable of providing a measure of spatial extent, with width, height, or length.

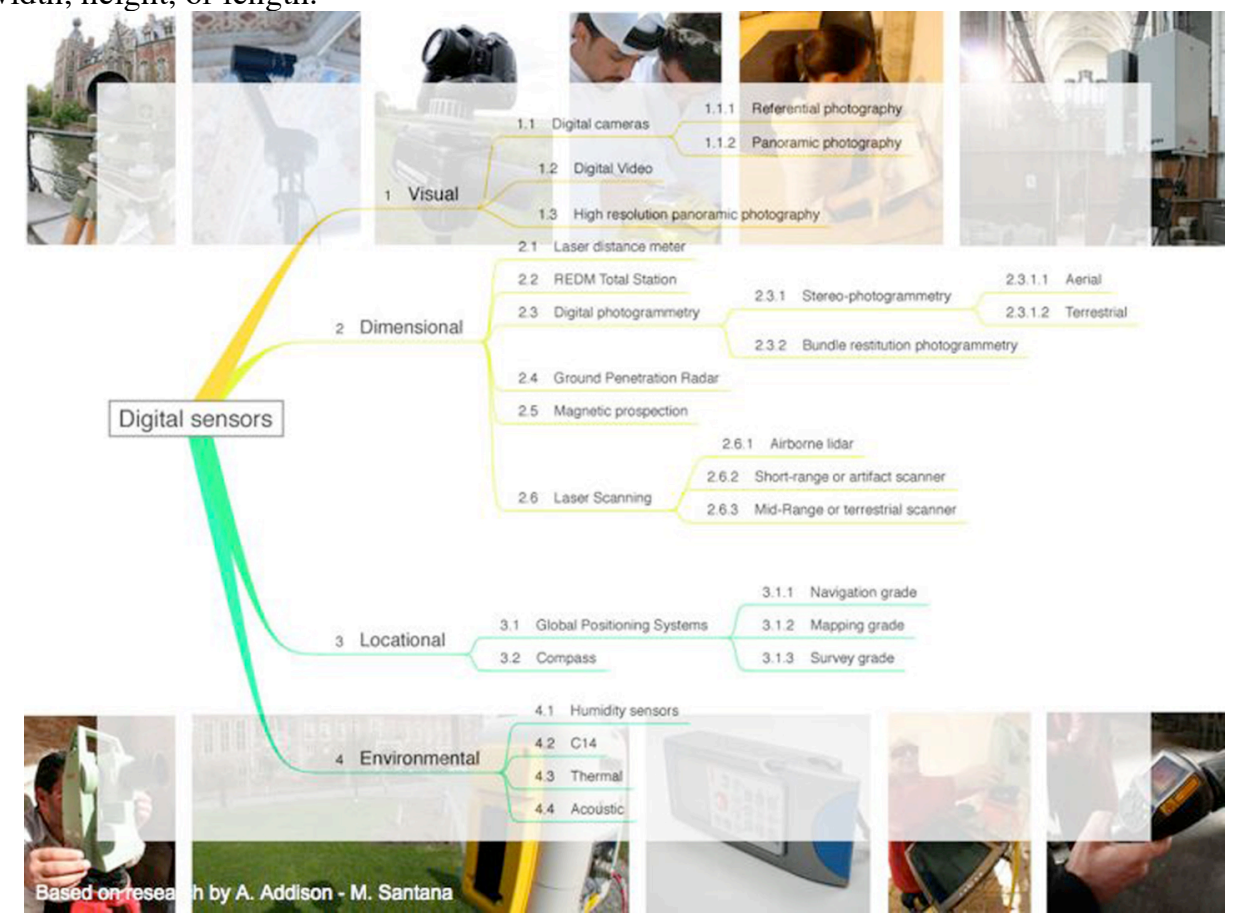

Figure 4: digital sensors in recording heritage information, based on Addison's approach. 
Locational: technology capable of providing the place where something is or could be located; a site, a location according to a national and/or international coordinate system (ex. UTM, longitude-Latitude, north orientation, etc).

Environmental: technology capable of providing information of potentially harmful factors originating in the environment, as well as, sensors providing 'dating' information, when a particular point or period of time at which something happened or existed.

\subsection{Heritage information: sensors (techniques) and site variables}

The careful study of variables dealing with the characteristics of sites (resources) to be studied and mapped in a heritage information system and their direct relation with the technology (sensors) available at hand would allow to predict the timeframe, institutional impact and budget requirements for the capturing of the indicators providing information to the system (see figure 5).

Heritage site variables:

- Accessibility (legal, environmental \& physical): time available and constraints accessing the site to carry out the survey.

- Budget: available funds for the survey.

- Expected quality: scale and level of detail expected from the survey.

- Timing: available timeframe to carry out the survey.

- Expertise: capacity of your staff to operate, process the data obtained from the sensor

- Quantification: existence, extend and quality of metric survey data available of the building.

- Other variables: additional constraints appropriate to the physical, social and cultural location of the site

- Project information needs:

- Condition mapping, inventory, management/conservation plans.

- Cyclic monitoring requirements. 


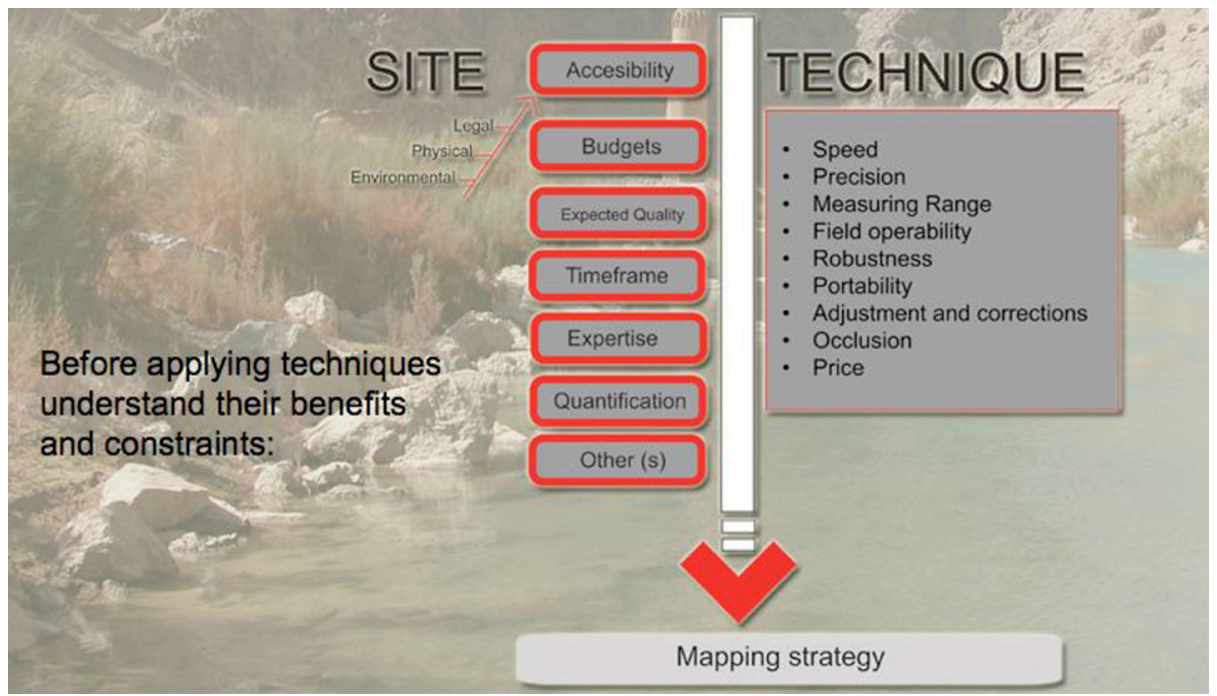

Figure 5: digital sensors and site variables in preparing a site baseline definition, author.

Sensor (technique) variables:

- Speed: time to record an indicator.

- Precision: accuracy factor of the capturing equipment.

- Measuring Range: reach of the tool, depends on distance and other environmental constraints.

- Field operability: constraints in relation to the fieldwork.

- Robustness: strength to extend adverse weather conditions and impact.

- Portability: capability of being transport to remote sites, requirements of transport, power and other factors.

- Adjustment and corrections: processes required to obtain accurate results.

- Occlusion: respond to shadows, obstacles, and material related constraints (reflectivity)

- Price: rental and/or purchase of the sensor.

\section{Training: heritage information capacity building}

Traditionally, heritage organizations assumed that the implementation of information system is unique to their organizations and this approach prevents them to allocate time to research to existing approaches, the issues affecting the adequate inventorying of cultural resources around the world is a global problem. Currently, several international initiatives have tackle this problem, allowing new approaches to be transmitted to experts and heritage organizations, among these experiences: 
- UNESCO's World Heritage Centre Development of a World Heritage Information Management capacity in the Arab States: this project seek to address the need of information systems applied to the protection of $\mathrm{WH}$ sites in the Arab region, there were two seminars organized for experts;

- ICCROM's Athar courses: Documentation and Management of Heritage Sites in the Arab Region: courses about the role of information in site management, using role play exercises;

- World Monuments Fund - Getty Conservation Institute Iraq Cultural Heritage Initiative: the establishment of a heritage information system for rapid-assessment of sites in Iraq, involving training courses in heritage information capturing, storing and management.

These experiences are focused in overcoming common issues in the utilization of heritage information systems, including:

- Lack of staff and institutional capacity and standards for collecting and referring information;

- Consistency in the identification and mapping of indicators for preventive strategies;

- $\quad$ Lack of long-term strategies to tackle longevity issues;

- Accessibility to technology

- Identification of funding

- Operational and institutional organization

Additionally, the CIPA's RecorDIM initiative has been seeking to produce training material for improving the consistency and use of standards for preparing heritage information systems.

\subsection{Basic guidelines:}

Currently, the following documents provide initial guide for the preparation of heritage information systems, it important to review them prior to start designing a system:

- ICOMOS Charter - Principles for the analysis, conservation and structural restoration of architectural heritage (ICOMOS 2003);

- ICOMOS Principles for the Recording of Monuments, Groups of Buildings and Sites (ICOMOS 1996);

- Council of Europe's Guidance on inventory and documentation of the cultural heritage (Council of Europe 2001);

- Council of Europe - Getty Information Institute's - The Core Data Index to Historic Buildings and Monuments of the Architectural Heritage (COE - GII 1998)

- Council of Europe - Getty Information Institute's - The International Core Standard for Archaeological Sites and Monuments (COE - GII 1998)

Although these documents provide a solid principles ground to start working, they do not provide strategic information about how to apply technology and adapt it to the institutional needs. 


\subsection{Proposals:}

In order to overcome the shortage of information on how to use documentation for heritage information practice, a number of guidelines are currently on the make, to assist in the preparation of heritage information system, including:

- ICOMOS resource manual on World Heritage Nomination fiels;

- RecorDIM's Information for Conservation (The Getty Conservation Institute);

- RecorDIM's Documentation for Conservation: Illustrated examples (The Getty Conservation Institute);

- RecorDIM's Documentation for Conservation: Metric Survey for Heritage Documentation: A manual for teaching Metric Survey Skills (English Heritage);

- $\quad$ EPOCH's heritage information scenarios (Addison - Santana).

\section{Current practices}

Additionally to the manuals, the following table is a preliminary assessment of current practices under development around the world, where information systems have been deployed for heritage conservation:

Table 2. Current practices

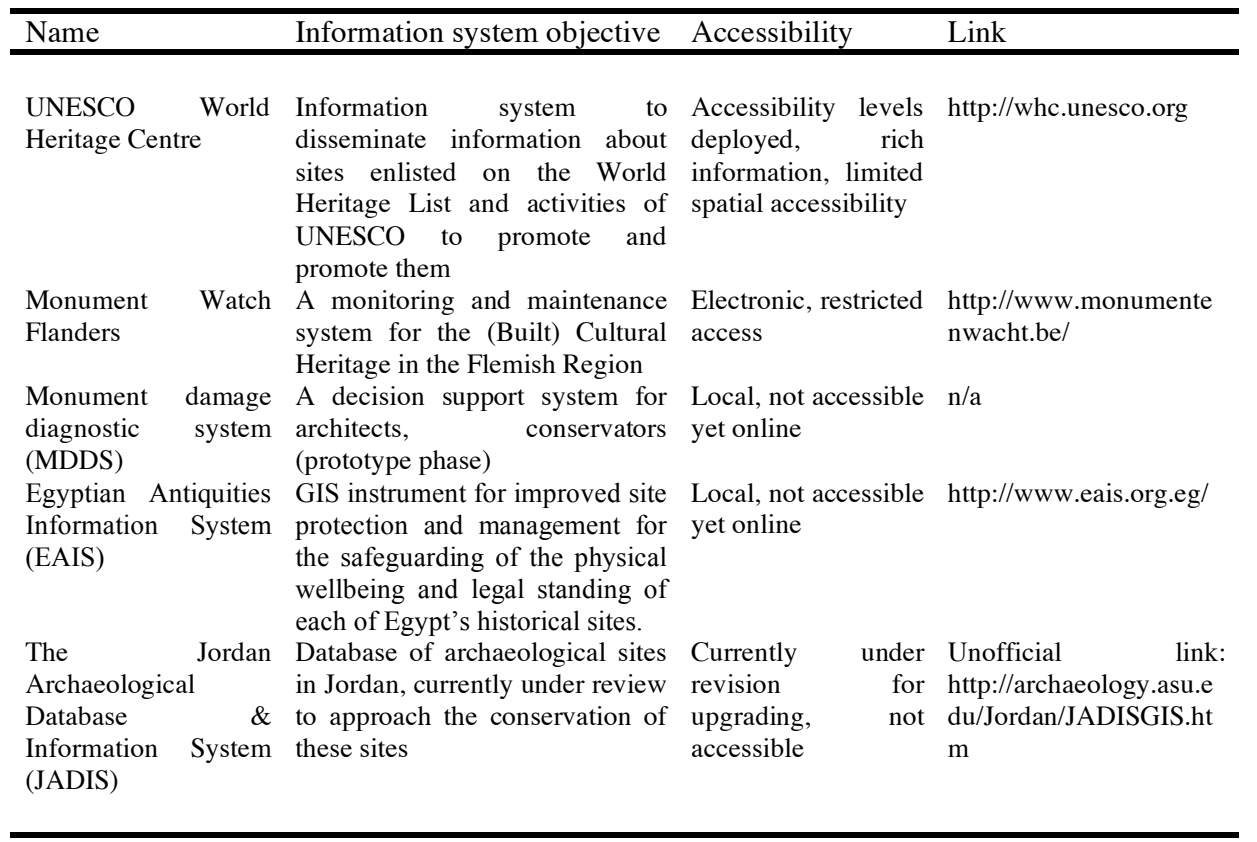


It is important to mention the lack of good practices in this field, and the lack of public accessibility of these information systems.

\section{Closing remarks}

Heritage information systems can play an important role to site managers in the planning process for allocating, managing, and applying for funding for the conservation of heritage sites.

Currently, the training gap in the preparation of these systems prevents managers to understand the utility and potential in their current work, capacity building should be a priority of international organizations providing training in developing countries around the world.

\section{Future work}

Future training initiative should also adopt a stakeholders approach in the preparation of heritage information systems, as well as, the ideas of preventive maintenance approach, where information is collected to prepare baseline information of the site and to subsequently continuous record interventions carried out.

\section{Acknowledgements}

The authors wish to acknowledge and thank the support of the Raymond Lemaire International Centre for Conservation for this opportunity of supporting this short research.

In addition, we would like to thank the support to this paper from my friends at RecorDIM and CIPA. Special thanks to Bill Blake, Alonzo Addison, and Rand Eppich.

Finally, we would like to thank all those individuals and institutions that in one way or the other helped with the completion of this report.

\section{References}

1. Box, P.: GIS and Cultural Resource Managements: A manual for Heritage Managers', UNESCO, Bangkok 1999.

2. Clark, K., Informed Conservation, English Heritage, London, 2001. 
3. Council of Europe, Guidance on Inventory and documentation of the cultural heritage, Council of Europe Publishing, Strasbourg, 2001.

4. Eppich, R. LeBlanc, F.: Documenting our past for the future, Getty Conservation Institute, http://www.getty.edu/conservation/publications/newsletters/20_3/feature.html (Last reviewed 19/06/2007)

5. Gillings, M. Wise, A.: GIS Guide to Good Practice, AHDS Guides to Good Practice, http://ads.ahds.ac.uk/project/goodguides/gis/index.html (Last reviewed 19/06/2007)

6. HABS/HAER/HALS, Preservation Architect, The Newsletter of The Historic Resources Committee, Washington, 2006.

7. ICCROM's Athar programme: Documentation and Management of Heritage Sites in the Arab Region http://www.iccrom.org/eng/prog200607_en/08athar_en/archive_en/2006_12documentation_en.shtml (Last reviewed 19/06/2007)

8. King, J. Ed.: Understanding Historic Buildings English Heritage Publishing, Swindon, UK 2006.

9. Parks Canada Periodic Report on the Application of the World Heritage Convention http://www.pc.gc.ca/docs/pm-wh/rspm-whsr/sec3/sec3c_e.asp (Last reviewed 19/06/2007)

10. Santana Quintero, M., The Use of Three-dimensional Documentation and Dissemination Techniques in Studying Built Heritage, R. Lemaire International Centre for Conservation (KU Leuven), Leuven , 2003.

11. Savage, S.: The Jordan Archaeological Database \& Information System (JADIS) http://archaeology.asu.edu/Jordan/JADISGIS.htm (Last reviewed 19/06/2007)

12. UNESCO's World Heritage Centre: Development of a World Heritage Information Management capacity in the Arab States http://whc.unesco.org/en/activities/58/ (Last reviewed 19/06/2007)

13. World Monuments Fund - Getty Conservation Institute Iraq Cultural Heritage Conservation Initiative http://www.getty.edu/conservation/field_projects/iraq/index.html http://www.wmf.org/iraq.html (Last reviewed 19/06/2007) 